\title{
Vulvar adenocarcinoma: visual resemblance to a vulvar abscess
}

\author{
Kailash Chandra Pandey, ${ }^{1}$ Swaroop Revannasiddaiah, ${ }^{1}$ Vipul Nautiyal, ${ }^{2}$ \\ Nirdosh Kumar Pant ${ }^{1}$
}

'Department of Radiation Oncology, Swami Rama Cancer Hospital \& Research Institute, Haldwani, Uttarakhand, India ${ }^{2}$ Department of Radiation Oncology, Dr. Ram Manohar Lohia Insitute of Medical Sciences, Lucknow, Uttar Pradesh, India

\section{Correspondence to} Dr Swaroop Revannasiddaiah, swarooptheone@gmail.com

\section{DESCRIPTION}

Abscesses of the vulvar and perineal regions are fairly common and very painful clinical entities warranting urgent surgical drainage. Here we describe the case of a woman who visited her primary care physician with symptoms of redness, swelling and severe pain over the right vulva (figure 1). As the patient had first noticed these symptoms less than a week previously, their

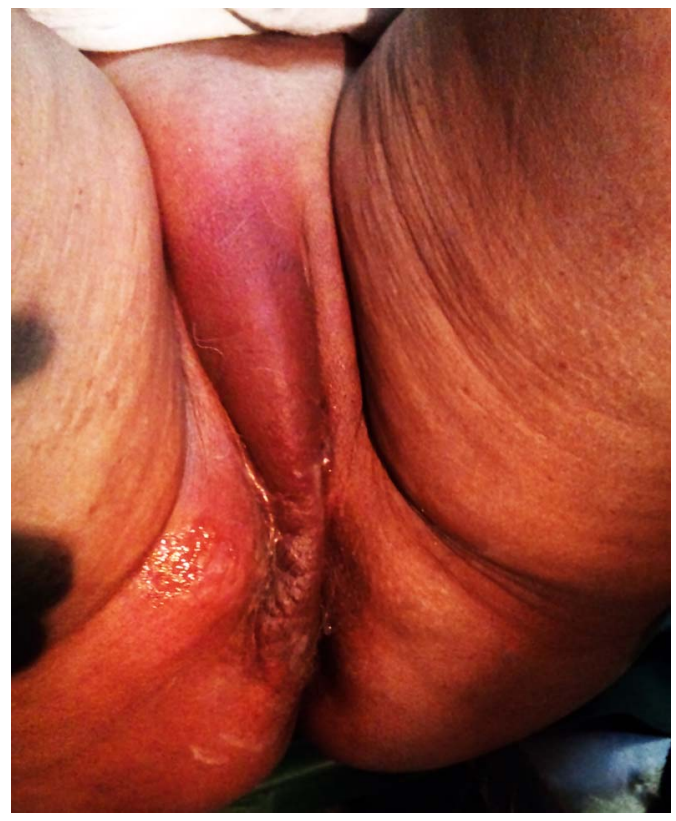

Figure 1 Clinical appearance at presentation. Features of acute inflammation, such as swelling and redness can be seen. The right vulva and the perineum were exquisitely tender.

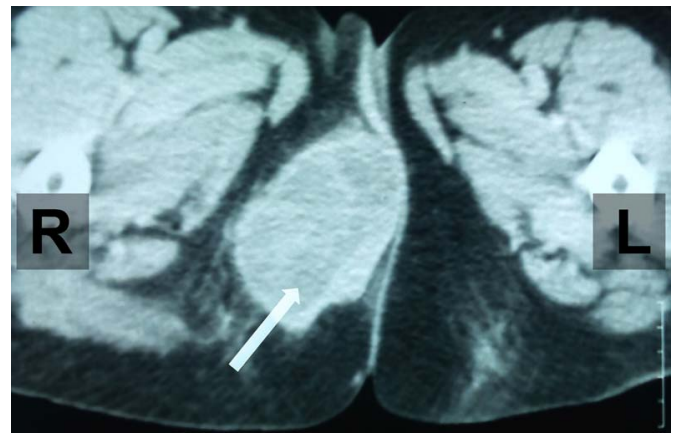

Figure 2 CT section demonstrating the presence of a solid mass lesion beneath the superficial inflammation.

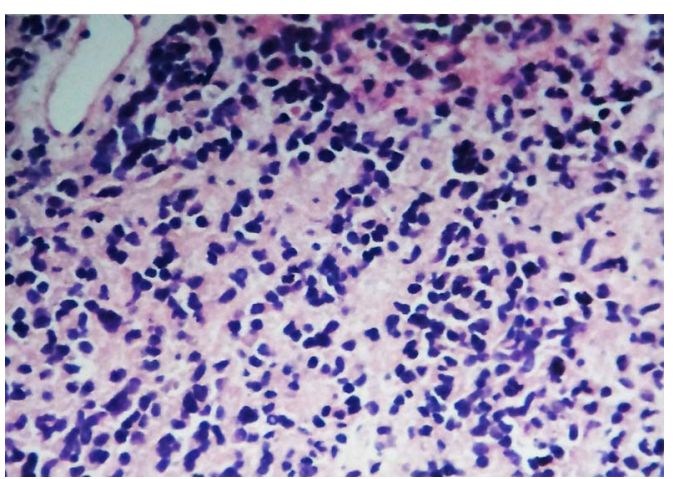

Figure 3 Histopathology demonstrating an adenocarcinoma with brisk mitotic activity.

apparently acute onset suggested a clinical diagnosis of vulvar abscess. However, this diagnosis was quickly shown to be incorrect when imaging (with ultrasonography and CT) demonstrated the presence of a mass within the vulva (figure 2). A biopsy of the lesion yielded a histopathological diagnosis of adenocarcinoma (figure 3). Most vulvar cancers are squamous cell carcinomas, with the remaining being adenocarcinomas, basal cell carcinomas, melanomas and sarcomas .12

The patient was also found to have multiple retroperitoneal lymph node deposits, as well as bilateral pulmonary metastases. Systemic chemotherapy with paclitaxel and carboplatin was initiated but the patient died 32 weeks after diagnosis. The presence of malignancy may not have been noticed by the patient earlier because the condition was not painful in the initial stages. The acute onset of pain in this case could possibly be due to abrupt enlargement or superadded infection.

\section{Learning points}

- Vulvar cancers are rare, comprising less than $4 \%$ of all gynaecological malignancies.

- Up to $90 \%$ of vulvar cancers are squamous cell carcinomas, with the remaining $10 \%$ comprising adenocarcinomas, basal cell carcinomas, melanomas and sarcomas.

- Given the rarity of vulvar malignancies, clinical suspicion remains low and they are very commonly mistaken for abscesses. 
Contributors KCP identified the case as worthy of publication. SR provided the clinical image and history. VP and NKP wrote the manuscript after a literature search.

Competing interests None.

Patient consent Obtained.

Provenance and peer review Not commissioned; externally peer reviewed.

\section{REFERENCES}

1 Hacker NF. Vulvar cancer. In: Berek JS, Hacker NF, eds. Practical gynecologic oncology. 3rd edn. Philadelphia: Williams and Wilkins, 2000:553-96.

2 Nayak AU, Sundari N, Nandini G. Wolf in lamb's skin: vulval carcinoma mimicking bartholin gland abscess. Indian I Sex Transm Dis 2009;30:46-7.

Copyright 2013 BMJ Publishing Group. All rights reserved. For permission to reuse any of this content visit http://group.bmj.com/group/rights-licensing/permissions.

BMJ Case Report Fellows may re-use this article for personal use and teaching without any further permission.

Become a Fellow of BMJ Case Reports today and you can:

- Submit as many cases as you like

- Enjoy fast sympathetic peer review and rapid publication of accepted articles

- Access all the published articles

- Re-use any of the published material for personal use and teaching without further permission

For information on Institutional Fellowships contact consortiasales@bmjgroup.com

Visit casereports.bmj.com for more articles like this and to become a Fellow 